\title{
Dr. Robert E. Scully: a tribute
}

\author{
Esther Oliva $\cdot$ Jaime Prat $•$ Robert H. Young
}

Received: 18 December 2012 / Accepted: 19 December 2012 /Published online: 24 January 2013

(C) Springer-Verlag Berlin Heidelberg 2013

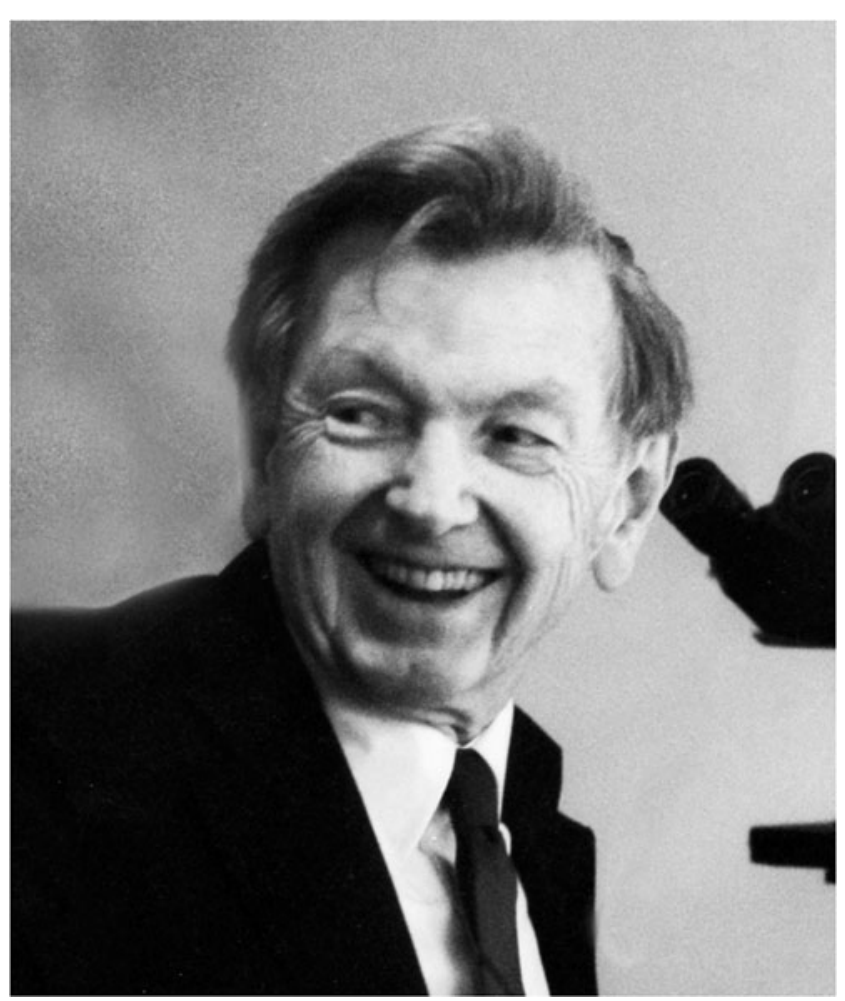

E. Oliva $\cdot$ R. H. Young

James Homer Wright Pathology Laboratories, Massachusetts

General Hospital, Harvard Medical School, Boston, MA, USA

J. Prat

Hospital de la Santa Creu i Sant Pau,

Universitat Autónoma de Barcelona, Barcelona, Spain

E. Oliva $(\triangle)$

Department of Pathology, Massachusetts General Hospital,

55 Fruit Street,

Boston, MA 02114, USA

e-mail: eoliva@partners.org
Robert E. Scully, MD, FRCPath, a giant in the field of pathology and the leading gynecologic pathologist of the last half century, died on October 30, 2012. He was born on August 31, 1921, graduated from Harvard Medical School in 1944, trained in pathology at the Peter Bent Brigham Hospital (now Brigham and Women's Hospital) and affiliated obstetric and gynecologic hospitals, and joined the faculty of the Massachusetts General Hospital (MGH) in 1950, remaining there (except for 2 years in the US army) until he retired in 2004.

Dr. Scully developed an early interest in gynecologic pathology, having spent time with Dr. Arthur T. Hertig during his training. His first papers, however, were on testicular tumors; he quickly became an expert in that area which remained a lifelong interest. His description of gonadoblastoma in 1953 heralded a similar major interest in the pathology of intersex. In 1958, Dr. Scully coauthored a book, Endocrine Pathology of the Ovary, which enhanced the reputation he was already acquiring for expertise in gynecologic pathology. The detailed coverage of sex cord stromal tumors of the ovary first revealed to a wide audience Dr. Scully's knowledge of unusual ovarian tumors, and he began to receive unusual cases in consultation. As years went by, the accrual of more and more interesting cases provided material for an increasing number of publications. The cases received for a second opinion eventually numbered over 27,000 . He looked at them from early in the morning until late in the day. Saturdays and Sundays were no different albeit he would leave a little earlier in the afternoon than during the work week. If this may suggest someone who was "all work and no play," Dr. Scully was a man of wide interests following sports, particularly his beloved Boston Red Sox, and the wider world with an interest in politics and the arts.

The number of articles describing new entities over the next decades is remarkable, perhaps the most significant being descriptions of special forms of sex cord stromal tumors such as juvenile granulosa cell tumor, the distinctive 
small cell carcinoma associated with hypercalcemia, the uterine Müllerian adenosarcoma, and uterine tumors that resemble ovarian sex cord tumors. A series of papers on metastatic tumors to the ovary, including an important one on spread of appendiceal tumors, represents a major body of work on that important category. One of us (JP) had the pleasure late in the 1970s of working up with him on unusual pseudosarcomatous nodules in mucinous tumors as well as sarcomas and anaplastic carcinomas complicating them. Another of us (EO) some years later had similar satisfaction describing under his guidance highly cellular leiomyomas, often misdiagnosed as endometrial stromal tumors prior to that paper.

Dr. Scully studied ovarian tumors by immunohistochemistry soon after the technique became established and a review of the topic published in 1985 is one of the first of its kind. An important earlier undertaking was his role as the pathologist who helped uncover the association of in utero exposure to DES with subsequent clear cell carcinoma of the vagina and cervix in their offspring.

Dr. Scully was the leader of the distinguished group that worked on the first World Health Organization classification of ovarian tumors, an undertaking that began in the early 1960s and was most influential because the disorderly classification of ovarian tumors that existed at the time was brought into a state of good order under Dr. Scully's overall guidance. He continued to be active in World Health Organization classifications being the senior writer of the classification of all female genital tract neoplasms ultimately published in the late 1990s.

Although he will be remembered primarily for his contributions to gynecologic pathology, Dr. Scully was a classically trained general anatomic pathologist with considerable experience with autopsy pathology and all areas of histopathology. Those who spent any period of time looking at cases with Dr. Scully quickly realized they were sitting with one of the greatest histopathologists. His eye was legendary not only because of the speed with which he would make difficult diagnoses but because of his great attention to detail and preparedness, if necessary, to study a very difficult case relentlessly making sure he left no stone unturned in arriving at the correct diagnosis.

For three decades in the middle to later years of his career, when he was busy with routine work and a heavy burden of consultation cases, and writing many original papers, Dr. Scully also was initially associate editor and then for 27 years editor of the Case Records of the MGH. This term as editor exceeded that of any of his predecessors. His great editorial skills and vast knowledge of medicine were of immense value in maintaining the standard of the publications, particularly when one reflects on how complicated many of the diseases were and the new techniques that became part of modern medicine making his work on the Case Records ever more challenging.

Dr. Scully received many awards, some of the most noteworthy being the Fred W. Stewart Award of the Memorial Sloan Kettering Cancer Center in New York, the Maude Abbott Lectureship and the Distinguished Pathologist Award of the US-Canadian Division of the International Academy of Pathology, Honorary Fellowship of the Royal College of Pathologists and "Doctor Honoris Causa" of the University of Leiden and the Autonomous University of Barcelona, and the Lifetime Achievement Award of the Massachusetts Medical Society. A named Professorship of Pathology in his honor was instituted at Harvard Medical School in the mid-1990s.

As much as he will be remembered for his unique contributions to the field of pathology, Dr. Scully will also be remembered for his great personal qualities, gentleness, humility, a wonderful wry sense of humor, and the ability to comfortably interact with all, from renowned leaders in medicine to individuals of less exalted stature, treating all with similar respect. He was simply beloved by the three writers of these words, and numerous others who had the privilege of working with him over the years, as well as countless residents who had the great good fortune to train under him. His legacy is rich, will endure, and will result in his being in the highest echelon of the great figures in anatomic pathology dating back to the founder of this journal and even earlier luminaries. 